\title{
The chondrogenic response to exercise in the proximal femur of normal and mdx mice
}

\author{
David J Nye', Jeffrey M Costas', Jessica B Henley', Jin-Kwang Kim², Jeffrey H Plochocki ${ }^{*}$
}

\begin{abstract}
Background: Submaximal exercise is used in the management of muscular dystrophy. The effects of mechanical stimulation on skeletal development are well understood, although its effects on cartilage growth have yet to be investigated in the dystrophic condition. The objective of this study was to investigate the chondrogenic response to voluntary exercise in dystrophin-deficient mice.

Methods: Control and dystrophin-deficient ( $\mathrm{mdx}$ ) mice were divided into sedentary and exercise-treated groups and tested for chondral histomorphometric differences at the proximal femur.

Results: Control mice ran $7 \mathrm{~km} /$ week further than mdx mice on average, but this difference was not statistically significant $(P>0.05)$. However, exercised control mice exhibited significantly enlarged femur head diameter, articular cartilage thickness, articular cartilage tissue area, and area of calcified cartilage relative to sedentary controls and exercised max mice $(P<0.05)$. No differences were found between other treatment groups.

Conclusions: $\mathrm{Mdx}$ mice exhibit a reduced chondrogenic response to increased mechanical stimulation relative to controls. However, no significant reduction in articular dimensions was found, indicating loss of chondral tissue may not be a clinical concern with dystrophinopathy.
\end{abstract}

\section{Background}

Genetic mutations affecting the expression of the dystrophin gene, as with Duchenne muscular dystrophy (DMD), impair cellular ability to resist muscle contractile forces and result in striated muscle cell death and fibrosis of the investing connective tissue [1,2]. Although there is no cure for muscular dystrophy, exercise has long been prescribed as a treatment modality $[3,4]$. Submaximal, low-intensity exercise has been shown to improve skeletal muscle performance [5], while rigorous exercise accelerates the dystrophic process [6-8]. Maintenance of muscle mass through exercise has also been shown to have musculoskeletal benefits related to gait, prolonged ambulation, and joint contracture $[3,9,10]$. While dystrophin deficiency does not directly affect bone and cartilage growth, the growth of these tissues is mechanically regulated and therefore indirectly affected by strains from muscle contraction [11]. Bone fractures, low bone mineral density, pelvic obliquity, and kyphoscoliosis have

\footnotetext{
* Correspondence: jploch@midwestern.edu

'Arizona College of Osteopathic Medicine, Midwestern University, Glendale, AZ 85308, USA

Full list of author information is available at the end of the article
}

been attributed to the effects of muscular degeneration and joint contractures on bone growth and maintenance in dystrophin-deficient patients [12-16]. However, the precise effects of moderate exercise on articular cartilage growth with dystrophinopathy-related muscle degeneration have yet to be studied.

We examine the effects of voluntary exercise activity on the proximal femurs of juvenile dystrophin-deficient (mdx) mice. Mdx mice do not have DMD, but exhibit a similar X-linked myopathy caused by dystrophin deficiency. Mdx mice have significantly reduced skeletal myocyte diameter, numerous necrotic myocytes, and abundant fibrosis leading to significantly weaker muscle force generation relative to wild-type mice and thus serve as a useful model for testing the effects of dystrophin-related muscle weakness $[17,18]$. Voluntary, rather than forced, exercise is used in our study because it has been shown to help maintain muscle strength in $\mathrm{mdx}$ mice and is similar to the submaximal, low-intensity exercise prescribed by some physicians in the management of human dystrophinopathies $[19,20]$.

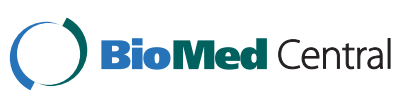

() 2010 Nye et al; licensee BioMed Central Ltd. This is an Open Access article distributed under the terms of the Creative Commons Attribution License (http://creativecommons.org/licenses/by/2.0), which permits unrestricted use, distribution, and reproduction in any medium, provided the original work is properly cited. 


\section{Methods}

Twenty mice of the control strain C57BL/10ScSn (000476; Jackson Laboratory, Bar Harbor, ME) and twenty mice of the dystrophin-deficient strain C57BL/ $10 \mathrm{ScSn}-\mathrm{Dmd}^{\mathrm{mdx}}$ (mdx mice; 001801; Jackson Laboratory, Bar Harbor, ME) were used in the experiment. The use of animals in this study was approved by the Institutional Animal Care and Use Committee at Midwestern University and follows NIH guidelines for animal research. All mice were 7 -week-old virgin females that were housed individually and provided with food and water ad libitum. Only females were used to control for potential sex differences. After a one-week acclimatization period, the mice were separated into four groups of equal size: sedentary control mice, exercise-treated control mice, sedentary mdx mice, and exercise-treated mdx mice. Exercise treatment consisted of voluntary access to a running wheel that lasted four weeks. Individual running distances were monitored using digital counters attached to each wheel. Following the fourweek treatment period, the mice were sacrificed using compressed $\mathrm{CO}_{2}$ at the age of 11 weeks.

Femurs were immediately excised and placed in decalcifier (Surgipath, USA) for 3 days. Once decalcification was complete, the femurs were frozen in liquid nitrogen and cryosectioned at a thickness of $12 \mu \mathrm{m}$ in the coronal plane. Sections were stained with toluidine blue to distinguish cartilage, calcified cartilage, and bone. Toluidine blue orthochromatic staining intensity of articular cartilage was observed to assess proteoglycan content of the tissue. Quantitative evaluation of toluidine blue stain is not recommended because of the variability of staining intensity and metachromasia related to decalcification, fixation, and $\mathrm{pH}$ of the tissue [21-24]. However, toluidine blue orthochromasia (i.e., blue appearance) is directly proportional to proteoglycan content of the tissue and thus suitable for a generalized qualitative assessment $[24,25]$.

Histomorphometric measurements were taken on digital images captured using an Eclipse 55i microscope (Nikon Inc.). Measurements included medial-lateral femoral head diameter, cartilage thickness at midjoint, area of the calcified cartilage zone, and cartilage tissue area excluding the calcified cartilage zone. Because of differences in body mass, statistical treatment of the data consisted of a general linear model of covariance (ANCOVA) with body weight as the covariate. Statistical significance was set at $P<0.05$.

\section{Results and Discussion}

Average daily running distance did not differ significantly between control and $\mathrm{mdx}$ mice $(\mathrm{P}>0.05$, Fig. 1$)$. On average, control mice ran $1.01 \mathrm{~km} /$ day more than

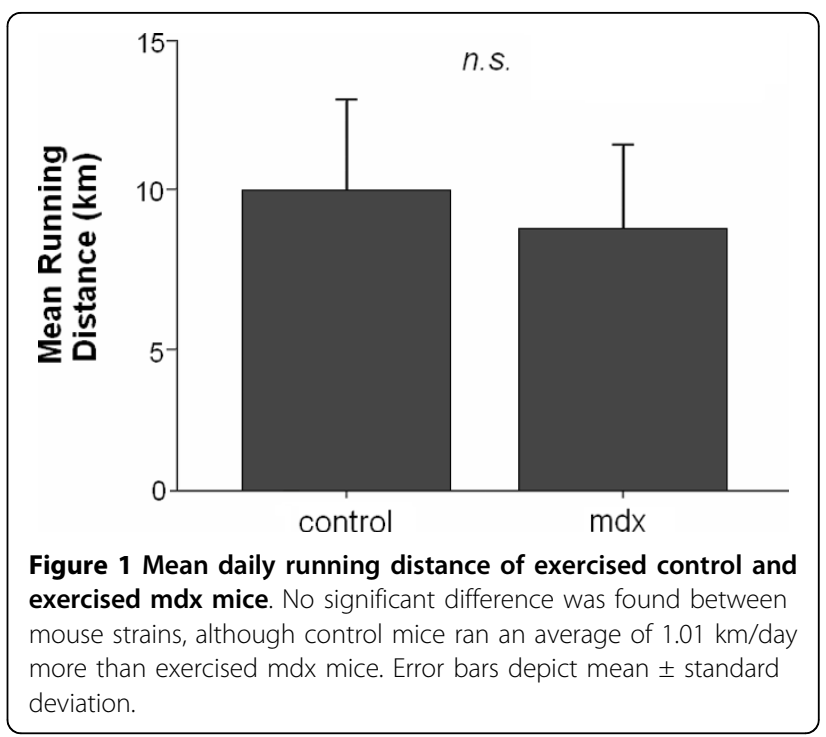

mdx mice. One mdx mouse did not run at all and was excluded from the analysis. Mdx mice were significantly heavier than controls in both the sedentary and exercise groups (Fig. 2). However, body mass did not differ significantly between sedentary and exercised mice of the control strain or between sedentary and exercised mdx mice.

Representative histological sections from each treatment group are shown in Fig 3. In general, the intensity of toluidine blue orthochromatic staining was greater in the control groups in comparison to mdx groups, indicating greater proteoglycan content in control mice.

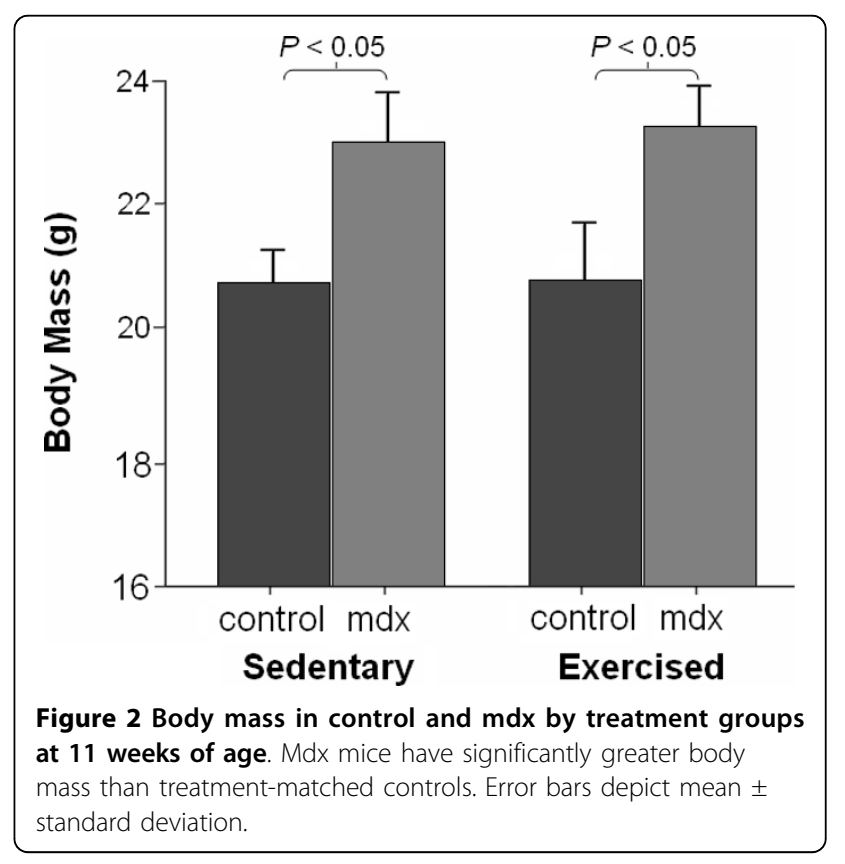




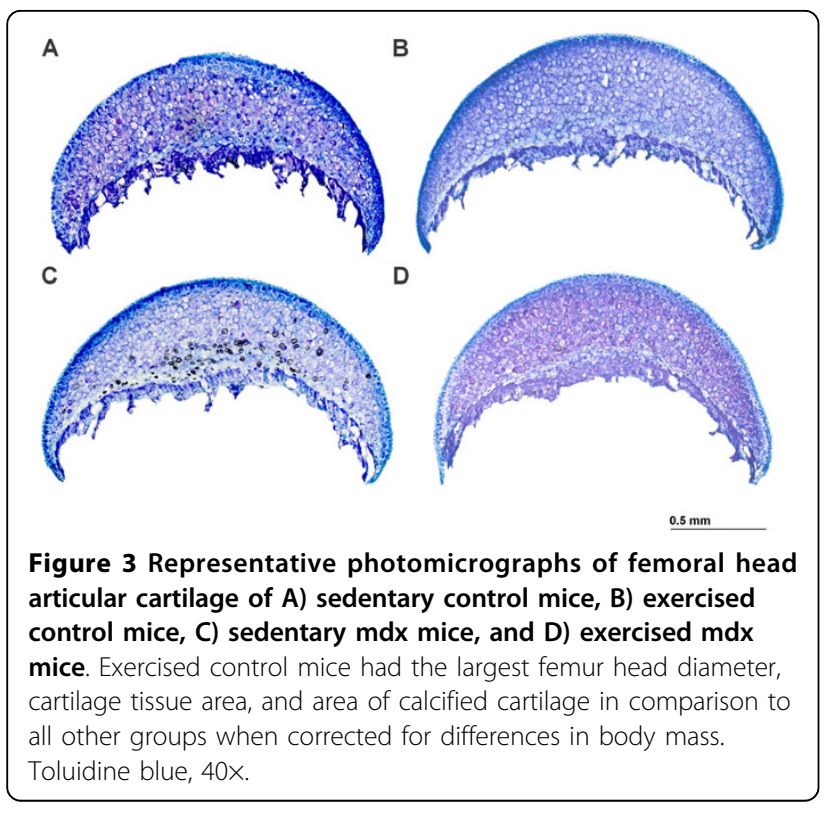

Statistical comparisons of histomorphometric parameters of the proximal femur corrected for body mass are displayed in Table 1. These data show that proximal femoral tissue of juvenile mdx mice is less responsive to mechanical stimulation in comparison with controls. No significant differences between sedentary and exercised $\mathrm{mdx}$ mice were found for any dependent variable included in the study $(P>0.05)$. However, femur head diameter, cartilage thickness, and cartilage tissue area are significantly larger in exercised controls relative to sedentary controls and exercised mdx mice $(P>0.05)$. There is an abundance of data demonstrating articular cartilage growth, bone growth, and the size of the calcification zone are sensitive to moderate exercise in healthy subjects [26-30]. In vitro studies confirm that mechanical loading of cartilage stimulates cell division and matrix synthesis $[31,32]$, even in the moderate range of $10 \mathrm{MPa}[33,34]$. In vivo, these effects translate to elevated chondral tissue expansion under increased mechanical stimulation $[28,35,36]$.
The lack of a chondrogenic response to voluntary exercise in mdx mice is a unique finding. Reduced mechanical loading and endocrinological changes may serve as possible explanations. First, it is conceivable that joint forces in mdx mice failed to provide sufficient mechanical pressure to yield significant chondral expansion. Skeletal muscle of mdx mice of similar age to the ones used in this study have been shown to contain extensive fibrosis and degenerative myocytes with diminished muscle force production $[17,37,38]$. While absolute force production of $\mathrm{mdx}$ hindlimb skeletal muscle has been reported to be similar to controls, muscle force normalized by muscle cross-sectional area is significantly reduced in $\mathrm{mdx}$ mice [38-40]. Thus, mdx mice are weaker for their given mass [39]. Studies have also found a significant and irreversible drop in force production during repeated eccentric muscle contraction in mdx mice that is attributed to dystrophic sarcolemma damage [41,42]. Such decreases in muscle force production accelerate fatigue, thereby reducing running endurance and speed $[42,43]$. For example, Hayes and Williams [44] found that $\mathrm{mdx}$ mice run an average of $0.5 \mathrm{~km} / \mathrm{hr}$ slower than controls. Running speed also plays a large role in determining joint forces. Faster mouse running speeds increase limb joint forces, even if ground reaction force remains constant [45]. Given these reported findings, a reduction in joint forces resulting from weaker muscle force production and slower running speeds may explain the diminished chondrogenic response to voluntary running exercise in the proximal femurs of $\mathrm{mdx}$ mice. However, more data is needed to confirm the role of mechanical factors affecting the functional adaptation of mdx mouse limb joints.

Second, it is also possible that endocrinological factors contributed to the poor chondrogenic response to exercise in the $\mathrm{mdx}$ mice. Proinflammatory cytokines, such as tumor necrosis factor-alpha (TNF- $\alpha$ ), are released during the breakdown and necrosis of dystrophic skeletal muscle myocytes [46-48]. TNF- $\alpha$ is a strong chemotactic agent

Table 1 Comparison of histomorphometric parameters of the proximal femur between treatment groups

\begin{tabular}{|c|c|c|c|c|c|c|c|c|}
\hline & \multicolumn{3}{|c|}{ Control } & \multicolumn{3}{|c|}{ Mdx } & \multirow{2}{*}{$\begin{array}{c}\begin{array}{c}\text { Sedentary control vs. } \\
\text { sedentary } \mathrm{mdx}\end{array} \\
P\end{array}$} & \multirow{2}{*}{$\begin{array}{c}\begin{array}{c}\text { Exercise control vs. } \\
\text { exercised } \mathrm{mdx}\end{array} \\
P\end{array}$} \\
\hline & Sedentary & Exercised & $P$ & Sedentary & Exercised & $P$ & & \\
\hline $\begin{array}{l}\text { Femur head } \\
\text { diameter }(\mathrm{mm})\end{array}$ & $1.363 \pm 0.066$ & $1.377 \pm 0.042$ & 0.03 & $1.273 \pm 0.112$ & $1.320 \pm 0.067$ & 0.22 & 0.12 & 0.01 \\
\hline $\begin{array}{l}\text { Cartilage } \\
\text { thickness ( } \mu \mathrm{m})\end{array}$ & $6.081 \pm 1.560$ & $5.878 \pm 0.651$ & 0.01 & $5.250 \pm 1.118$ & $5.058 \pm 0.872$ & 0.70 & 0.46 & 0.01 \\
\hline $\begin{array}{l}\text { Calcified cartilage } \\
\text { area }\left(\mu \mathrm{m}^{2}\right)\end{array}$ & $0.143 \pm 0.041$ & $0.206 \pm 0.022$ & 0.01 & $0.172 \pm 0.038$ & $0.180 \pm 0.072$ & 0.49 & 0.29 & 0.13 \\
\hline $\begin{array}{l}\text { Cartilage Area } \\
\left(\mathrm{mm}^{2}\right)\end{array}$ & $0.909 \pm 0.170$ & $0.949 \pm 0.082$ & 0.01 & $0.811 \pm 0.131$ & $0.775 \pm 0.095$ & 0.88 & 0.09 & 0.01 \\
\hline
\end{tabular}

Values are mean \pm standard deviation; ANCOVA for dependent variables with body mass as a covariate. 
that attracts neutrophils and macrophages to damaged tissue and can contribute to the degradation of healthy tissue. Several studies have found elevated levels of TNF$\alpha$ in both skeletal muscle and blood plasma of dystrophin-deficient patients $[49,50]$. Circulating TNF- $\alpha$ in dystrophin-deficient mice could potentially affect articular cartilage where it is known to attenuate chondrocytic synthesis of proteoglycans and collagen [51-53]. Although detecting TNF- $\alpha$ was beyond the scope of this study, if present, the inhibitory effect on chondrocyte extracellular matrix production could explain the reduced chondrogenic response to running activity and the weak toluidine blue orthochromatic staining observed in the mdx mice relative to controls (Fig. 3). However, future studies are needed to examine proinflammatory cytokine levels in skeletal muscle, blood serum, and synovial fluid in the dystrophic condition to elucidate their relationship with chondrocyte metabolism and articular cartilage histomorphometric properties.

There is also the possibly that the inhibition of dystrophin expression in chondrocytes may affect chondrocyte proliferation and secretion of extracellular matrix, although this seems unlikely. To our knowledge, no study has identified dystrophin synthesis in chondrocytes. Additionally, other connective tissue cells, such as fibroblasts, do not produce detectable amounts of dystrophin $[53,54]$. Thus it remains unclear what role, if any, dystrophin plays in cartilage tissue growth and maintenance. Nonetheless, this possibility should be explored in future studies.

It should be noted that chondral tissues of the $\mathrm{mdx}$ mice, although not enlarged, are also not significantly reduced in size relative to sedentary controls (Table 1). Both reduced mechanical stimulation and increased levels of TNF- $\alpha$ can retard articular tissue growth, leading to thinner articular cartilage and smaller joints [30,55-57]. Our data suggests that chondrogenic activity in both the sedentary and exercised mdx mice aged 11 weeks is still sufficient to maintain articular tissue size comparable to sedentary controls. These findings are of interest to clinicians because, 1) low intensity exercise is sometimes used in the management of muscular dystrophy, and 2) muscular dystrophy patients lead a more sedentary lifestyle. Although the mdx mouse model does not perfectly reproduce the progression and severity of the dystrophic process observed in humans, by 6 weeks of age mdx mice exhibit significant muscle weakness and thus serve as a useful model for studying dystrophinrelated muscle-skeletal tissue interactions [11]. Our findings suggest that the addition of articular tissue during postnatal growth is limited in $\mathrm{mdx}$ mice. However, chondral tissue area was preserved in the sedentary groups, indicating loss of chondral tissue is not a major concern with dystrophin deficiency. This may explain the lack of articular cartilage involvement in dystrophinopathies.

\section{Conclusions}

The results of this study show mdx mice exhibit a reduced chondrogenic response to increased mechanical stimulation relative to controls. Voluntary running exercise does not significantly affect femur head diameter, cartilage thickness, cartilage tissue area, and calcified cartilage tissue area in mdx mice as it does in controls. However, articular dimensions analyzed in this study were not reduced in mdx mice in comparison with controls, suggesting loss of chondral tissue may not be a clinical concern with dystrophinopathy.

\section{Acknowledgements}

The authors are thankful to Midwestern University for supporting this research. The authors would also like to thank Erin Simons for helpful criticism during revision of the manuscript.

\section{Author details}

${ }^{1}$ Arizona College of Osteopathic Medicine, Midwestern University, Glendale, AZ 85308, USA. ${ }^{2}$ The Pennsylvania State University, University Park, PA 16802, USA.

\section{Authors' contributions}

DJN, MJC, JBH, and JHP contributed to the design of the experiments. JBH was primarily responsible for animal care and treatment. DJN was responsible for data collection. DJN and JHP were equally responsible for data analysis and drafting the manuscript. J-KK aided in the revision of the manuscript and interpretation of the data. All authors have read and approved the final manuscript.

\section{Competing interests}

The authors declare that they have no competing interests.

Received: 15 March 2010 Accepted: 3 September 2010

Published: 3 September 2010

\section{References}

1. Grounds MD, Sorokin L, White J: Strength at the extracellular matrixmuscle interface. Scand J Med Sci Sports 2005, 15:381-91.

2. Weller B, Karpati G, Carpenter S: Dystrophin-deficient mdx muscle fibers are preferentially vulnerable to necrosis induced by experimental lengthening contractions. J Neurol Sci 1990, 100:9-13.

3. Scott M, Hyde SA, Goddard C, Jones R, Dubowitz V: Effect of exercise in Duchenne muscular dystrophy. A controlled six-month feasibility study of the effects of two different regimes of exercises in children with Duchenne muscular dystrophy. Physiotherapy 1981, 67:174-76.

4. Vignos PJ Jr, Watkins MP: The effect of exercise in muscular dystrophy. $J$ Am Med Assoc 1966, 197:843-48.

5. Sveen M-L, Jeppesen TD, Hauerslev A, Krag TO, Vissing J: Endurance training: an effective and safe treatment for patients with LGMD2I. Neurology 2007, 68:59-61.

6. Grange RW, Call JA: Recommendations to define exercise prescription for Duchenne muscular dystrophy. Exerc Sport Sci Rev 2007, 35:12-17.

7. Hudecki MS, Pollina CM, Granchelli JA, Daly MK, Byrnes T, Wang JC, Hsiao JC: Strength and endurance in the therapeutic evaluation of prednisolone-treated mdx mice. Res Commun Chem Pathol Pharmacol 1993, 79:45-60.

8. Sandri M, Podhorska-Okolow M, Geromel V, Rizzi C, Arslan P, Franceschi C, Carraro U: Exercise induces myonuclear ubiquitination and apoptosis in dystrophin-deficient muscle of mice. J Neuropathol Exp Neurol 1997, 56:45-57. 
9. Ansved T: Muscular dystrophies: influence of physical conditioning on the disease evolution. Curr Opin Clin Nutr Metab Care 2003, 6:435-39.

10. Eagle M: Report on the muscular dystrophy campaign workshop: exercise in neuromuscular diseases Newcastle, January 2002. Neuromuscul Disord 2002, 12:975-83

11. Montgomery E, Pennington C, Isales CM, Hamrick MW: Muscle-bone interactions in dystrophin-deficient and myostatin-deficient mice. Anat Rec A Discov Mol Cell Evol Biol 2005, 286:814-22.

12. Cambridge W, Drennan JC: Scoliosis associated with Duchenne muscular dystrophy. J Pediatr Orthop 1987, 7:436-40.

13. Furderer S, Hopf C, Zollner J, Eysel P: Scoliosis and hip flexion contracture in Duchenne muscular dystrophy. Z Orthop Ihre Grenzeb 2000, 138:131-35.

14. Larson CM, Henderson RC: Bone mineral density and fractures in boys with Duchenne muscular dystrophy. J Pediatr Orthop 2000, 20:71-74.

15. McDonald DG, Kinali M, Gallagher AC, Mercuri E, Muntoni F, Roper H, Jardine $P$, Jones DH, Pike MG: Fracture prevalence in Duchenne muscular dystrophy. Dev Med Child Neurol 2002, 44:695-98.

16. Vestergaard P, Glerup H, Steffensen BF, Rejnmark L, Rahbek J, Mosekilde L: Fracture risk in patients with muscular dystrophy and spinal muscular atrophy. J Rehab Med 2001, 33:150-55.

17. Roig M, Roma J, Fargas A: Longitudinal pathologic study of the gastrocnemius muscle group in mdx mice. Acta Neuropathol 2004 107:27-34

18. Connolly AM, Keeling RM, Mehta S, Pestronk A, Sanes JR: Three mouse models of muscular dystrophy: the natural history of strength and fatigue in dystrophin-, dystrophin/utrophin-, and laminin alpha-2deficient mice. Neuromusc Disord 2001, 11:703-12.

19. Landisch RM, Kosir AM, Nelson SA, Baltgalvis KA, Lowe DA: Adaptive and nonadaptive responses to voluntary wheel running by $\mathrm{mdx}$ mice. Muscle Nerve 2008, 38:1290-03

20. Wagner KR, Lechtzin N, Judge DP: Current treatment of adult Duchenne muscular dystrophy. Biochim Biophys Acta 2007, 1772:229-37.

21. French JE, Benditt EP: The histochemistry of connective tissue. II. The effect of proteins on the selective staining of mucopolysaccharides by basic dyes. J Histochem Cytochem 1953, 1:321-25.

22. Engfeldt B, Hjertquist SO: Studies on the epiphyseal growth zone. The preservation of acid glycosaminoglycans in tissues in some histotechnical procedures for electron microscopy. Virchows Arch [Zellpathol] 1968, 1:222-29.

23. Kiviranta I, Tammi M, Jurvelin J, Säämänen AM, Helminen HJ: Fixation, decalcification, and tissue processing effects on articular cartilage proteoglycans. Histochem 1984, 80:569-73.

24. Rosenberg $L$ : Chemical basis for the histological use of safranin $O$ in the study of articular cartilage. J Bone Joint Surg 1971, 53:69-82.

25. Shepard N, Mitchell N: Simultaneous localization of proteoglycan by light and electron microscopy using toluidine blue O: A study of epiphyseal cartilage. J Histochem Cytochem 1976, 24:621-29.

26. Isaksson H, Tolvanen V, Finnilä MA, livarinen J, Tuukkanen J, Seppänen K, Arokoski JP, Brama PA, Jurvelin JS, Helminen HJ: Physical exercise improves properties of bone and its collagen network in growing and maturing mice. Calcif Tissue Int 2009, 85:247-56.

27. Kiviranta I, Tammi M, Jurvelin J, Saamanen AM, Helminen HJ: Moderate running exercise augments glycosaminoglycans and thickness of articular cartilage in the knee joint of young beagle dogs. J Orthop Res 1988, 6:188-95.

28. Plochocki JH, Riscigno CJ, Garcia M: Functional adaptation of the femoral head to voluntary exercise. Anat Rec 2006, 288:776-81.

29. Tranquille CA, Blunden AS, Dyson SJ, Parkin TDH, Goodship AE, Murray RC: Effect of exercise on thicknesses of mature hyaline cartilage, calcified cartilage, and subchondral bone of equine tarsi. Am J Vet Res 2009, 70:1477-83.

30. van de Lest $\mathrm{CH}$, Brama PA, Van Weeren PR: The influence of exercise on the composition of developing equine joints. Biorheology 2002, 39:183-91.

31. Elder SH, Fulzele KS, McCulley WR: Cyclic hydrostatic compression stimulates chondroinduction of $\mathrm{C} 3 \mathrm{H} / 10 \mathrm{~T} 1 / 2$ cells. Biomech Mod Mechanobiol 2005, 3:141-46.

32. Wu QQ, Chen Q: Mechanoregulation of chondrocyte proliferation, maturation, and hypertrophy: ion-channel dependent transduction of matrix deformation signals. Exp Cell Res 2000, 256:383-91.

33. Ikenoue T, Trindade MCD, Lee MS, Lin EY, Schurman DJ, Goodman SB, Smith RL: Mechanoregulation of human articular chondrocyte aggrecan and type II collagen expression by intermittent hydrostatic pressure in vitro. J Orthop Res 2003, 21:110-16.

34. Smith RL, Lin J, Trindade MC, Shida J, Kajiyama G, Vu T, Hoffman AR, van der Meulen MC, Goodman SB, Schurman DJ, Carter DR: Time-dependent effects of intermittent hydrostatic pressure on articular chondrocyte type II collagen and aggrecan mRNA expression. J Rehabil Res Dev 2000 37:153-61

35. Hammond AS, Ning J, Ward CV, Ravosa MJ: Mammalian limb loading and chondral modeling during ontogeny. Anat Rec 2010, 293:658-70.

36. Wang $X$, Mao JJ: Chondrocyte proliferation of the cranial base cartilage upon in vivo mechanical stresses. J Dent Res 2002, 81:701-05.

37. Carlson C, Makiejus R: A noninvasive procedure to detect muscle weakness in the mdx mouse. Muscle Nerve 1990, 13:480-84.

38. Lynch G, Hinkle R, Chamberlain J, Brooks S, Faulkner J: Force and power output of fast and slow skeletal muscles from mdx mice 6-28 months old. J Physiol 2001, 535:591-600.

39. Coulton GR, Curtin NA, Morgan JE, Partridge TA: The mdx mouse skeleta muscle myopathy: II. Contractile properties. Neuropathol Appl Neurobiol 2008, 14:299-314

40. Sacco P, Jones DA, Dick JR, Vrbova G: Contractile properties and susceptibility to exercise-induced damage of normal and $\mathrm{mdx}$ mouse tibialis anterior muscle. Clin Sci 1992, 82:227-36

41. Blaauw B, Mammucari C, Toniolo L, Agatea L, Abraham R, Sandri M, Reggiani C, Schiaffino S: Akt activation prevents the force drop induced by eccentric contractions in dystrophin-deficient skeletal muscle. Hum Mol Genet 2008, 17:3686-96.

42. Moens $P$, Baatsen PH, Maréchal G: Increased susceptibility of EDL muscles from mdx mice to damage induced by contractions with stretch. $J$ Muscle Res Cell Motil 1993, 14:446-51.

43. Carter GT, Wineinger MA, Walsh SA, Horasek SJ, Abresch RT, Fowler WM Jr: Effect of voluntary wheel-running exercise on muscles of the $\mathrm{mdx}$ mouse. Neuromuscul Disord 1995, 5:323-32.

44. Hayes A, Williams DA: Beneficial effects of voluntary wheel running on the properties of dystrophic mouse muscle. J Appl Physiol 1996, 80:670-79

45. Heglund NC, Taylor CR: Speed, stride frequency, and energy cost per stride: How do they change with body size and gait. J Exp Biol 1988, 138:301-18.

46. Hodgetts S, Radley H, Davies M, Grounds MD: Reduced necrosis of dystrophic muscle by depletion of host neutrophils, or blocking TNF $\alpha$ function with Etanercept in mdx mice. Neuromusc. Disord 2006, 16:591-602.

47. Pierno S, Nico B, Burdi R, Liantonio A, Didonna MP, Cippone V, Fraysse B, Rolland JF, Mangieri D, Andreetta F, Ferro P, Camerino C, Zallone A, Confalonieri P, De Luca A: Role of tumour necrosis factor $\alpha$, but not of cyclo-oxygenase-2-derived eicosanoids, on functional and morphological indices of dystrophic progression in mdx mice: a pharmacological approach. Neuropathol Appl Neurobiol 2007, 33:344-59.

48. Radley HG, Davies MD, Grounds MD: Reduced muscle necrosis and longterm benefits in dystrophic mdx mice after cV1q (blockade of TNF) treatment. Neuromusc Disord 2008, 18:227-38.

49. Porreca E, Guglielmi MD, Uncini A, Di Gregorio P, Angelini A, Di Febbo C, Pierdomenico SD, Baccante G, Cuccurullo F: Haemostatic abnormalities, cardiac involvement and serum tumor necrosis factor levels in X-linked dystrophic patients. Thromb Haemost 1999, 81:543-46.

50. Saito K, Kobayashi D, Komatsu M, Yajima T, Yagihashi A, Ishikawa Y, Minami R, Watanabe N: A sensitive assay of tumor necrosis factor alpha in sera from Duchenne muscular dystrophy patients. Clin Chem 2000, 46:1703-04.

51. Reginato AM, Sanz-Rodriguez C, Diaz A, Dharmavaram RM, Jimenez SA: Transcriptional modulation of cartilage-specific collagen gene expression by interferon gamma and tuniotir necrosis Factor alpha in cultured human chondrocytes. Biochem J 1993, 194:761-69.

52. Saklatvala J: Tumour necrosis factor alpha stimulates resorption and inhibits synthesis of proteoglycan in cartilage. Nature 1986, 312:547-49.

53. Lakonishok M, Muschler J, Horwitz AF: The alpha 5 beta 1 integrin associates with a dystrophin-containing lattice during muscle development. Dev Biol 1992, 152:209-20.

54. Miranda AF, Bonilla E, Martucci G, Moraes CT, Hays AP, Dimauro S: Immunocytochemical study of dystrophin in muscle cultures from 
patients with Duchenne muscular dystrophy and unaffected control patients. Am J Pathol 1988, 132:410-16.

55. Hagiwara Y, Ando A, Chimoto E, Saijo Y, Ohmori-Matsuda K, Itoi E: Changes of articular cartilage after immobilization in a rat knee contracture model. J Orthop Res 2009, 27:236-42.

56. Stevens AL, Wishnok JS, White FM, Grodzinsky AJ, Tannenbaum SR: Mechanical injury and cytokines cause loss of cartilage integrity and upregulate proteins associated with catabolism, immunity, inflammation, and repair. Mol Cell Proteomics 2009, 8:1475-89.

57. Steinberg ME, Trueta J: Effects of activity on bone growth and development in the rat. Clin Orthop Relat Res 1981, 156:52-60.

\section{Pre-publication history}

The pre-publication history for this paper can be accessed here: http://www.biomedcentral.com/1471-2474/11/198/prepub

doi:10.1186/1471-2474-11-198

Cite this article as: Nye et al:: The chondrogenic response to exercise in the proximal femur of normal and mdx mice. BMC Musculoskeletal

Disorders 2010 11:198.

\section{Submit your next manuscript to BioMed Central} and take full advantage of:

- Convenient online submission

- Thorough peer review

- No space constraints or color figure charges

- Immediate publication on acceptance

- Inclusion in PubMed, CAS, Scopus and Google Scholar

- Research which is freely available for redistribution

Submit your manuscript at www.biomedcentral.com/submit 